\title{
Prospective randomized controlled clinical study comparing two dental implant types: volumetric soft tissue changes at 1 year of loading
}

\author{
Sanz Martin, Ignacio ; Benic, Goran I ; Hämmerle, Christoph H F ; Thoma, Daniel S
}

\begin{abstract}
OBJECTIVE To evaluate the volumetric changes occurring from prosthesis insertion to the 1-year follow-up (FU) using one- and two-piece dental implants. METHODS Sixty patients were randomly assigned to receive one-piece or two-piece implants. Casts were obtained at baseline (insertion of final reconstruction) and at 1 year of loading. Finally, 33 pairs of casts $(B R A=18, S T M=15)$ were deemed appropriate for volumetric analysis of the peri-implant tissues. If the patients had more than one implant, one was randomly selected for analysis. Casts were scanned to obtain stereolithography (STL) files. Baseline and 1-year FU digital models were superimposed with an image analysis program. Linear and volumetric measurements were performed including (i) crown height changes (CHCs), (ii) volumetric changes, and (iii) changes in tissue thickness at three levels below the mucosal margin on the buccal side of the implants (at 1,3, and $5 \mathrm{~mm}$ ). The Mann-Whitney U-test and the paired t-test were used to analyze the data between the two groups using the patient as the unit of analysis. RESULTS No significant baseline differences were observed between the one- and two-piece groups for the linear measurements. The mean CHCs in the two-piece group amounted to $0.02 \mathrm{~mm}$ (SD \pm 0.32 ), whereas the one-piece group exhibited a change of $-0.17 \mathrm{~mm}( \pm 0.57)$. The mean volume changes $(\mathrm{VCs})$ were $-0.12 \mathrm{~mm}( \pm 0.27)$ (two-piece group) and $-0.03 \mathrm{~mm}( \pm 0.29)$ (one-piece group). With regard to the changes in tissue thickness, the two-piece group presented a change of $-0.15 \mathrm{~mm}( \pm 0.20)$ at $1 \mathrm{~mm},-0.06 \mathrm{~mm}( \pm 0.20)$ at $3 \mathrm{~mm}$, and $-0.2 \mathrm{~mm}( \pm 0.51)$ at $5 \mathrm{~mm}$. The respective values for the one-piece group were $-0.03 \mathrm{~mm}( \pm 0.35), 0.01 \mathrm{~mm}( \pm 0.28)$, and $-0.01 \mathrm{~mm}( \pm 0.51)$ at the three levels. None of the differences in linear measurements between baseline and the 1-year FU reached significance. Positive correlations were seen for tissue thickness changes at 1 and $3 \mathrm{~mm}$ for both groups $(\mathrm{P}<$ 0.05). Significant positive correlations were found for VCs and tissue thickness at $1 \mathrm{~mm}$ for the two-piece group and for VCs and tissue thickness at 1,3 , and $5 \mathrm{~mm}$ for the one-piece group $(\mathrm{P}<0.05)$. CONCLUSION Within the first year of loading, minimal changes occur with regard to tissue thickness, crown height, and facial volume for both implant types.
\end{abstract}

DOI: https://doi.org/10.1111/clr.12579

Posted at the Zurich Open Repository and Archive, University of Zurich

ZORA URL: https://doi.org/10.5167/uzh-110302

Journal Article

Accepted Version

Originally published at:

Sanz Martin, Ignacio; Benic, Goran I; Hämmerle, Christoph H F; Thoma, Daniel S (2016). Prospective randomized controlled clinical study comparing two dental implant types: volumetric soft tissue changes at 1 year of loading. Clinical Oral Implants Research, 27(4):406-411.

DOI: https://doi.org/10.1111/clr.12579 


\section{Prospective randomized controlled clinical study comparing two dental implant types: volumetric soft tissue changes at one year of loading.}

Ignacio Sanz Martin *, Goran I. Benic †, Christoph H.F. Hämmerle †, Daniel S. Thoma +

* Section of Periodontology, Faculty of Odontology, University Complutense of Madrid, Madrid, Spain.

$\dagger$ Clinic of Fixed and Removable Prosthodontics and Dental Material Science, Center for Dental Medicine, University of Zurich, Zurich, Switzerland

Address for correspondence: PD Dr. Daniel S. Thoma Clinic of Fixed and Removable Prosthodontics and Dental Material Science

Center of Dental Medicine, University of Zurich Plattenstrasse 11 $\mathrm{CH}-8032$ Zurich, Switzerland Phone: +4116343252

Fax: +411634 4305 (do not publish) e-mail: daniel.thoma@zzm.uzh.ch

Word Count Manuscript: 2944

Number of figures and tables: 3 figures, 4 tables.

Running title: Volumetric soft tissue changes with two implant systems 


\section{ABSTRACT}

Objective: to evaluate the volumetric changes occurring from prosthesis insertion to the one year follow-up using one- and two-piece dental implants.

\section{Methods:}

60 patients were randomly assigned to receive one-piece or two-piece implants. Casts were obtained at baseline (insertion of final reconstruction) and at one year of loading. Finally, 33 pairs of casts $(B R A=18, S T M=15)$ were deemed appropriate for volumetric analysis of the peri-implant tissues. If the patients had more than one implant, one was randomly selected for analysis. Casts were scanned to obtain stereolithography (STL) files. Baseline and one-year follow-up digital models were superimposed with an image analysis program. Linear and volumetric measurements were performed including: i) crown height changes, ii) volumetric changes and, iii) changes in tissue thickness at three levels below the mucosal margin on the buccal side of the implants (at 1,3 and $5 \mathrm{~mm}$ ). The Mann-Whitney U-test and the paired ttest were used to analyze the data between the two groups using the patient as the unit of analysis.

\section{Results:}

No significant baseline differences were observed between the one- and two-piece groups for the linear measurements. The mean crown height changes in the twopiece group amounted to $0.02 \mathrm{~mm}(S D \pm 0.32$ ), whereas the one-piece group exhibited a change of $-0.17 \mathrm{~mm}( \pm 0.57)$. The mean volume changes were $-0.12 \mathrm{~mm}^{3}$ $( \pm 0.27)$ (two-piece group) and $-0.03 \mathrm{~mm}^{3}( \pm 0.29)$ (one-piece group). With regards to the changes in tissue thickness, the two-piece group presented a change of $0.15 \mathrm{~mm}( \pm 0.20)$ at $1 \mathrm{~mm},-0.06 \mathrm{~mm}( \pm 0.20)$ at $3 \mathrm{~mm}$ and $-0.2 \mathrm{~mm}( \pm 0.51)$ at $5 \mathrm{~mm}$. The respective values for the one-piece group were $-0.03 \mathrm{~mm}( \pm 0.35), 0.01 \mathrm{~mm}$ 
$( \pm 0.28)$ and $-0.01 \mathrm{~mm}( \pm 0.51)$ at the three levels. None of the differences in linear measurements between baseline and the one-year follow-up reached significance. Positive correlations were seen for tissue thickness changes at 1 and $3 \mathrm{~mm}$ for both groups $(p<0.05)$. Significant positive correlations were found for volume changes and tissue thickness at $1 \mathrm{~mm}$ for the two-piece group and for volume changes and tissue thickness at 1,3 and $5 \mathrm{~mm}$ for the one-piece group $(p<0.05)$.

Conclusion: Within the first year of loading minimal changes occur with regards to tissue thickness, crown height and facial volume for both implant types. 


\section{KEY WORDS}

"dental implants", "humans", "crown", "fixed, partial, denture", "soft tissue", "volumetric analysis" 


\section{INTRODUCTION:}

The increased predictability of dental implants has driven researchers and clinicians not only to focus on implant survival, but also on additional outcome measures that define a successful implant therapy. This includes parameters such as technical, biological and esthetic complications as well as implant failures (Jung, et al. 2012a, Papaspyridakos, et al. 2012).

Along these lines more emphasis has recently been given to the appearance of both the peri-implant tissues and the prosthetic restorations. When evaluating the implant literature the parameters most often reported are the level of the mucosal margin, the appearance of the interdental papillae, the color of the mucosal, and the esthetics of the mucosa and the reconstruction (Benic, et al. 2012). Together with other relevant parameters, such as marginal bone levels, the assessment of the changes in tissue contour by means of volumetric analysis can give further insights and offers new prospectives in the analysis of the behaviour of the peri-implant soft tissues.

Two of the potential variables identified as playing a major role in the preservation of peri-implant tissues have been the implant neck design and type (Bateli, et al. 2011, Laurell \& Lundgren 2011). Although there is a large variety of implant head and neck configurations available on the market, implant systems can generally be divided into one- and two-piece dental implant types. One-piece dental implants are characterized by the fact that the anchorage unit and the contiguous prosthetic/transmucosal component are manufactured as one piece. Two-piece dental implants have the anchorage component and the element of the prosthetic/transmucosal component manufactured as two separate pieces (Cehreli, et al. 2004, Hermann, et al. 2001). 
The behavior of these two types of dental implant systems has widely been studied. The bulk of the information published reports on clinical soft tissue parameters and interproximal bone levels measured on peri-apical radiographs (Astrand, et al. 2002, Astrand, et al. 2004, Cochran, et al. 2009).

In the past, little attention has been given to the quality and quantity of the periimplant tissues, which were reported to be key parameters in implant esthetics (Cairo, et al. 2008, Cosyn, et al. 2012a, Thoma, et al. 2014a). The impact these two different treatment concepts possibly have on the stability of the peri-implant buccal soft tissues during loading remains unknown.

The assessment of the volume of the peri-implant tissues is challenging due to the paucity of tools suitable to evaluate not only hard, but also soft tissue changes. Recently, digital optical scanning and assessment methods have been applied with the aim of measuring volume changes of oral tissues over time. Calibration studies demonstrated precision and reliability of these methods to assess soft tissue volume changes in a non-invasive way (Windisch, et al. 2007). This method has successfully been used to assess the volume changes in the alveolar process in conjunction with soft and hard tissue augmentation in preclinical and clinical studies (Schneider, et al. 2011, Thoma, et al. 2010).

The aim of the present study was therefore to assess the volumetric changes of the buccal soft tissues between baseline and one year of loading comparing a one- and a two-piece dental implant type. 


\section{MATERIALS AND METHODS}

\section{Study design}

The study was designed as a randomized controlled clinical study. Following approval by the local ethical committee, sixty consecutively admitted patients seeking dental implant therapy at the Clinic of Fixed and Removable Prosthodontics and Dental Material Science, Center of Dental Medicine, University of Zurich, Switzerland were included in the study. These patients were treated and randomly assigned to receive dental implants of either the one-piece type (Institut Straumann, Basel, Switzerland; STM) or the two-piece type (Brånemark, Nobel Biocare, Zurich, Switzerland; BRA). Randomization was performed using a computer-generated list. Details regarding inclusion and exclusion criteria as well as the surgical, regenerative and prosthetic procedures can be found in an earlier publication reporting on the demographic data and the radiographic outcomes (Thoma, et al. 2014b).

\section{Model Fabrication}

Alginate impressions were taken at the baseline examination (BL) and at the oneyear follow-up (FU). Dental stone casts were fabricated immediately after the impressions were obtained, resulting in 60 pairs of models. Models were evaluated for the presence of irregularities such as porous areas, undefined gingival margins, broken cusps or undefined vestibulum. Only casts obtained from patients that received implant single crowns or fixed partial dentures were included. After this examination, 33 pairs of casts ( $B L$ and $F U$ ) were deemed appropriate for volumetric analysis (15 BRA, 18 STM).

STL (stereolithography) image acquisition, matching of data and volumetric analysis 
The cast models were optically scanned with a desktop 3D scanner (Imetric 3D, Courgenay, Switzerland). Baseline and one-year follow-up STL files of the models of the 33 patients were uploaded to an image analysis software (Swissmeda Software, Swissmeda AG, Zürich, Switzerland). In order to match the STL files, three clear and visible common reference points were selected in both the baseline and one-year follow-up casts. After the selection of these references, the software automatically superimposed the models using a series of mathematical algorithms (Figure 1).

\section{Image analysis}

In case patients had received more than one dental implant, one of these was randomly chosen for the linear and volumetric analysis in each pair of casts. Measurements were performed by a calibrated, blinded outside evaluator. The following measurements were performed:

i) Linear measurements: A longitudinal slice that divided the crown mesio-distally into two equal parts was selected. A line coinciding with the axis of the tooth was then drawn in the transversal images of the sections. At both baseline and the oneyear follow-up the apico-coronal dimension of the clinical crown $(\mathrm{CH})$ was assessed by measuring the distance between two lines perpendicular to the axis of the tooth coinciding with the most prominent cusp and the gingival margin at baseline and one-year follow up. In order to evaluate the estimated soft tissue thickness (eTT), a line parallel to the axis of the tooth was drawn contacting the most coronal aspect of the gingival margin. The distance between this line and buccal soft outline was then assessed at 1,3 and $5 \mathrm{~mm}$ below the gingival margin at both time points (Figure 2).

ii) Volumetric measurements: The area used to evaluate the volume changes was bordered by the mucosal margin at the implant restoration, by the mesial and distal line angles and extended $5-6 \mathrm{~mm}$ apically (Figure 3 ). The software then calculated 
the volume change (VC) measured in $\mathrm{mm}^{3}$, which corresponds to the volume enclosed between the two surfaces involved within the designed area.

\section{Radiographic measurements}

The radiographic analysis performed has been described in detail in a previous publication (Thoma et al. 2014). In brief, intraoral radiographs of all implants were taken at the baseline and at the one-year follow-up examination using a paralleling technique with Rinn-holders and analog films (Kodak Ektaspeed plus; Eastman Kodak CO, Rochester, NY, USA). All radiographs were digitized and marginal bone levels changes analyzed using an open-source software (Image J, National Institutes of Health, Bethesda, MD, USA). For this paper, only implants and sites with measurable casts were included.

\section{Statistical analysis}

Descriptive statistics (means, standard deviations, medians and IQRs) of continuous variables were computed for each system separately using a statistical software program (SPSS Version 18.0, IBM corporation. New York, USA). One implant per patient was randomly chosen as test implant rendering a total of 33 implants analyzed (15BRA, 18STM). The data was tested for normality by means of a Kolmogorov-Smirnov test and found to be normally distributed. The Mann-Whitney test was used to disclose differences for continuous variables. Moreover, the paired t-test for crown height changes, mean volume changes and linear measurements at 1,3 and $5 \mathrm{~mm}$ was provided together with the corresponding $\mathrm{p}$-values and $95 \%$ confidence intervals for each system separately. In order to disclose associations between continuous variables the Spearman correlation was utilized. Statistical significance was set at the alpha level of 0.05 . 


\section{RESULTS}

A total of 33 patients (two-piece group $=18$ patients; one-piece group $=15$ patients) with one randomly selected implant were included in the analyses for volumetric and linear changes. Patients in the two-piece group were restored with 14 single crowns (SCs) and 4 fixed partial dentures (FDPs), whereas patients in the one-piece group were restored with 11 SCs and 4 FDPs.

In the two-piece group a total of 14 patients received guided bone regenerative procedures by means of a native collagen membrane (Bio-Gide, Geistlich Pharma AG, Wolhusen, Switzerland) and a demineralized bovine bone substitute (Bio-Oss, Geistlich Pharma AG, Wolhusen, Switzerland). The same procedure was performed for 13 implants in the one-piece group. The defect configurations consisted of implant dehiscences ranging from $1-5 \mathrm{~mm}$ and apical fenestrations. A total of six patients with six implants (two-piece group: 4 patients; one-piece: 2 patients) did not receive any bone regenerative procedure.

\section{Baseline $(B L)$ linear and radiographic measurements}

In the two-piece group, the mean crown height was $8.85 \mathrm{~mm}$ (standard deviation $\pm 1.9)$, whereas in the one-piece group this value amounted to $9.7 \mathrm{~mm}( \pm 1.9)$. Regarding the estimated tissue thickness, in the two-piece group the values at $1 \mathrm{~mm}$, $3 \mathrm{~mm}$ and $5 \mathrm{~mm}$ were $0.75 \mathrm{~mm}( \pm 0.31), 1.31 \mathrm{~mm}( \pm 0.78)$ and $1.82 \mathrm{~mm}( \pm 1.08)$, while in the one-piece group these values were $0.93 \mathrm{~mm}( \pm 0.52), 1.46 \mathrm{~mm}( \pm 0.93)$ and $1.7 \mathrm{~mm}( \pm 1.13)$. Regarding the radiographic parameters, the DIB (distance between the implant shoulder and the marginal bone level) for the two-piece group was $0.93 \mathrm{~mm}( \pm 0.42)$ and $0.68 \mathrm{~mm}( \pm 0.93)$ for the one-piece group. There were no 
statistically significant differences between the two groups for the linear and radiographic measurements (Table 1 ).

Linear, volumetric and radiographic changes between BL and FU

In the two-piece group, the mean crown height changes $(\mathrm{CHC})$ amounted to $0.02 \mathrm{~mm}$ $( \pm 0.32)$, while the one-piece group exhibited a change of $-0.17 \mathrm{~mm}( \pm 0.57)$. The mean volume change (VC) was $-0.12 \mathrm{~mm}^{3}( \pm 0.27)$ (two-piece group) and $-0.03 \mathrm{~mm}^{3}$ ( \pm 0.29$)$ (one-piece group).

With regards to the changes in tissue thickness, the two-piece group presented a change of $-0.15 \mathrm{~mm}( \pm 0.20)$ at $1 \mathrm{~mm},-0.06 \mathrm{~mm}( \pm 0.20)$ at $3 \mathrm{~mm}$ and $-0.2 \mathrm{~mm}$ $( \pm 0.51)$ at $5 \mathrm{~mm}$. The respective values for the one-piece group were $-0.03 \mathrm{~mm}$ $( \pm 0.35), 0.01 \mathrm{~mm}( \pm 0.28)$ and $-0.01 \mathrm{~mm}( \pm 0.51)$ at the three levels.

The mean radiographic bone level changes in the two-piece group presented a mean loss of $0.08 \mathrm{~mm}( \pm 0.2)$, while the one-piece group presented a loss of $0.35 \mathrm{~mm}$ $( \pm 0.35)$. The differences between the two groups reached statistical significance $(p=0.01)$

No other statistically significant differences between the two groups were observed for any of the above-mentioned parameters $(p>0.05)$ (Table2).

\section{Correlations}

When analyzing the correlations between variables in the two-piece group, positive correlations reaching statistical significance were found between the changes in tissue thickness at $1 \mathrm{~mm}$ and $3 \mathrm{~mm}(p=0.02)$ between $3 \mathrm{~mm}$ and $5 \mathrm{~mm}(p=0.02)$, and between the mean volume change and the tissue thickness at $1 \mathrm{~mm}(p=0.01)$ (Table 3). In the one-piece group, positive correlations reaching statistical significance were found between the changes in tissue thickness at $1 \mathrm{~mm}$ and $3 \mathrm{~mm}(p=0.04)$, $1 \mathrm{~mm}$ and $5 \mathrm{~mm}(p=0.01)$ and, between tissue thickness at $3 \mathrm{~mm}$ and $5 \mathrm{~mm}(p=0.01)$. 
In the same group, statistical significance was also reached with a positive correlation between mean volume change and tissue thickness at all three levels (1mm: $p<0.001,3 \mathrm{~mm}: \mathrm{p}=0.004$ and $5 \mathrm{~mm}: \mathrm{p}=0.04)$ (Table 4). Since there were only a minimal number of sites (6) without bone regeneration, no correlations were calculated for this outcome parameter. 


\section{DISCUSSION}

In the present investigation minimal changes were observed at the one-year followup evaluation with regards to tissue thickness, crown height and facial tissue volume without significant differences between the two-piece and one-piece implant type. The one-piece group demonstrated, however, higher marginal bone levels at the one-year control.

Dental implants have demonstrated high long-term survival rates over 5 and 10 years of follow-up (Jung, et al. 2012b, Pjetursson, et al. 2012). Despite of these positive results little information has been provided regarding other relevant parameters that may influence the appearance of the restoration with respect to the soft tissues.

In reconstructive implant dentistry, pleasing esthetics have been defined as an appearance showing harmony between the natural and the reconstructed parts of the dentition (Belser, et al. 2004a, Belser, et al. 2004b). It appears crucial that once the restoration is delivered the achieved results remain stable over time. For this purpose, adequately designed investigations that follow patients over time are of paramount importance.

A recently published systematic review revealed a great heterogeneity in the parameters and methods utilized to evaluate the esthetic appearance of an implant restoration (Benic, et al. 2012). Moreover, it was found that the indexes utilized to assess the esthetics of implant supported restorations were observer dependent, and only reached moderate reproducibility between observers (den Hartog, et al. 2011). In the same manner, photographs were found to be a non-reliable method for objective evaluation of esthetic parameters since they are prone to the distortion resulting from different angles of view and light exposures (Weinlander, et al. 2009). Therefore, it appears that there is a need to provide objective and quantitative 
information regarding the parameters that may influence the esthetics at dental implants.

The differences found in the present investigation between both implant systems in terms of marginal bone levels are not surprising since the subjects evaluated represent a sample of a previously published investigation that showed similar tendencies (Thoma, et al. 2014b).

When comparing the linear and volumetric parameters followed over time, there were no significant differences between the two implants systems. Whereas the twopiece group had less changes in regards to crown height (0.02 vs $-0.17 \mathrm{~mm})$, it appeared to lose slightly more volume over time (-0.12 vs $\left.-0.03 \mathrm{~mm}^{3}\right)$. In addition, it exhibited more pronounced changes in tissue thickness at the $1 \mathrm{~mm}$ level ($0.15 \mathrm{~mm}$ vs $-0.03 \mathrm{~mm})$.

The interpretation of these results is difficult since there are several parameters that may influence the position and stability of the mucosal margin at dental implants such as the buco-lingual implant position (Chen, et al. 2009, Cosyn, et al. 2012b). Moreover, one would expect that the tendencies shown favoring the two-piece group in terms of crown height changes would be coupled with similar values in the tissue thickness at $1 \mathrm{~mm}$, which was obviously not the case.

The most prominent difference between these two implant systems is the presence of a smooth collar in the one-piece group that represents the beginning of the prosthetic components. This given emergence profile may limit the capability of the restorative dentist to control the initial emergence of the prosthesis which may ultimately translate into changes in the level of the mucosal margin (crown height changes). On the other hand, this smooth collar may act as a stabilizer of the soft tissues preventing them from collapse; this hypothesis may explain the greater 
stability shown in terms of tissue thickness and volume change in the one-piece group.

When analyzing the correlations between the different variables there was no significant association between tissue thickness at the three different levels evaluated and the marginal bone levels for the two groups. These results are in contrast with recently published investigations that found a significant association between patient's biotype and interproximal bone levels (Linkevicius, et al. 2009a, b). These contrasting results may be explained by the fact that the subjects in the quoted investigations were divided according to their periodontal biotype (thin and thick). Moreover, the methodology of assessing the tissue thickness varies between these investigations and the present clinical trial. Whereas the mentioned investigations measured only the tissue thickness, the present report measured the distance between a line parallel to the axis of the implant and the buccal soft tissue outline at three different levels. It appears prudent to mention that the periodontal biotype or the tissue thickness primarily evaluate the facial aspect of the implant, whereas intraoral radiographs analyze the interproximal bone levels. Therefore, it appears understandable that these two parameters do not correlate.

With regards to the other parameters evaluated, both systems showed correlations between the tissue thickness at 1 and $3 \mathrm{~mm}$, between tissue thickness at 3 and $5 \mathrm{~mm}$ and between tissue thickness at $1 \mathrm{~mm}$ and volume changes. These positive correlations are somehow expected, since the tissue thickness and the volume change measure a localized part of the facial area of the restoration and the changes in this area are likely to influence all of these parameters. Besides the previously mentioned correlations, the one-piece group showed a significant association between the volume change and the crown height. Moreover, the one-piece group as 
well showed a positive association between tissue thickness at $3 \mathrm{~mm}$ and $5 \mathrm{~mm}$ and volume change. The reason for the differences found between the two groups remains unclear.

Other publications have analyzed the stability of the peri-implant tissue over time. In a clinical case series the changes in tissue height and volume were evaluated at different times in patients requiring implant supported restorations in the esthetic zone (Schneider, et al. 2011). It was demonstrated that following the intervention with augmentation procedures, the peri-implant tissue remained stable over time. The soft and hard tissue changes were assessed using a methodology similar to the one in the present study. Drawing comparisons with the presented results appears difficult, since the designs of the investigations vary and, in this investigation, two different implant systems were utilized.

The potential effect of the regenerative procedures on the mucosal morphology is an aspect to be taken into consideration. The long-term stability of regenerated buccal peri-implant bone by means of bone substitutes has been recently assessed by three-dimensional imaging (Jung, et al. 2013). The authors reported that after 5 years of evaluation the buccal vertical bone gain remained stable, moreover the periimplant soft tissue height and thickness seemed to be compatible with health and its dimensions were comparable to the ones found in implants placed in native bone.

The present investigation appears to be the first report analyzing the volumetric stability of the peri-implant tissues comparing two different implant designs over time. It must be taken into consideration that the study has some limitations since the sample utilized was selected and reduced based on the patients that presented adequate models for evaluation. The evaluated areas were mostly areas that were subject to regenerative procedures and different types of fixed restorations were utilized. In combination with classic clinical and radiographic measures, this approach 
offered a more complete three-dimensional picture of outcomes following implant therapy and allowed analyzing the changes of peri-implant tissues over time in a non-invasive way. 


\section{CONCLUSIONS}

In conclusion, the present study demonstrated high peri-implant tissue stability for both implant types over the short-term observation of period of the first year of loading. No significant differences were found between the two implant types with regards to tissue thickness, crown height and facial volume. The two-piece group exhibited slightly less bone loss during the evaluated period. 


\section{ACKNOWLEDEMENTS}

The authors greatly acknowledge the help of Tiffany Graf, Clinic of Fixed and Removable Prosthodontics and Dental Material Science, School for Dental Medicine, University of Zurich for performing the scans of the casts and the making the volumetric measurements.

\section{CONFLICTS OF INTERESTS}

This study was funded by the Clinic of Fixed and Removable Prosthodontics and Dental Material Science, School for Dental Medicine, University of Zurich, Zurich, Switzerland. Dr. Ignacio Sanz Martin received an ITI post-graduate Scholarship

during the conduct of the study. Goran Benic, Christoph Hammerle and Daniel Thoma report no conflict of interest. 


\section{FIGURE LEGENDS}

Figure 1. Stereolithography (STL) image superimposition of baseline (yellow) and one-year (green) follow-up models.

Figure 2. Volume comparison. The colored area (mint) represents the area analyzed.

Figure 3. Outline of baseline and one-year follow-up models and linear measurements performed in central section. Baseline model (yellow) and one year follow-up (green). $\mathrm{CH}=$ clinical crown height. eTT1= estimated tissue thickness at $1 \mathrm{~mm}$ below the gingival margin. eTT3= estimated tissue thickness at $3 \mathrm{~mm}$ below the gingival margin . eTT5=tissue thickness at $5 \mathrm{~mm}$ below the gingival margin.

Table 1. Linear measurements and radiographic parameters at baseline.

$\mathrm{SD}=$ standard deviation. $\mathrm{CH}=$ crown height. $\mathrm{DIB}=$ distance between implant shoulder and marginal bone level.

Table 2. Changes between baseline and one-year follow-up in linear measurements, volumetric measurements and radiographic parameters. SD=standard deviation. $\mathrm{CHC}=$ clinical crown change. $\mathrm{VC}=$ volumetric change. $\mathrm{DIB}=$ distance between implant shoulder and marginal bone level.

Table 3. Correlations between variables in the two-piece group (correlation coefficient and significance). $\mathrm{CHC}=$ clinical crown change. $\mathrm{VC}=$ volumetric change. $\mathrm{DIB}=$ distance between implant shoulder and marginal bone level.

Table 4. Correlations between variables in the one-piece group (correlation coefficient and significance). $\mathrm{CHC}=$ clinical crown change. $\mathrm{VC}=$ volumetric change. DIB = distance between implant shoulder and marginal bone level. 


\section{REFERENCES}

Astrand, P., Engquist, B., Anzen, B., Bergendal, T., Hallman, M., Karlsson, U., Kvint, S., Lysell, L. \& Rundcrantz, T. (2002) Nonsubmerged and submerged implants in the treatment of the partially edentulous maxilla. Clinical Implant Dentistry and Related Research 4: 115-127.

Astrand, P., Engquist, B., Anzen, B., Bergendal, T., Hallman, M., Karlsson, U., Kvint, S., Lysell, L. \& Rundcranz, T. (2004) A three-year follow-up report of a comparative study of iti dental implants and branemark system implants in the treatment of the partially edentulous maxilla. Clinical Implant Dentistry and Related Research 6: 130141.

Bateli, M., Att, W. \& Strub, J. R. (2011) Implant neck configurations for preservation of marginal bone level: A systematic review. International Journal of Oral and Maxillofacial Implants 26: 290-303.

Belser, U., Buser, D. \& Higginbottom, F. (2004a) Consensus statements and recommended clinical procedures regarding esthetics in implant dentistry. International Journal of Oral and Maxillofacial Implants 19 Suppl: 73-74.

Belser, U. C., Schmid, B., Higginbottom, F. \& Buser, D. (2004b) Outcome analysis of implant restorations located in the anterior maxilla: A review of the recent literature. International Journal of Oral and Maxillofacial Implants 19 Suppl: 30-42.

Benic, G. I., Wolleb, K., Sancho-Puchades, M. \& Hammerle, C. H. (2012) Systematic review of parameters and methods for the professional assessment of aesthetics in dental implant research. Journal of Clinical Periodontology 39 Suppl 12: 160-192.

Cairo, F., Pagliaro, U. \& Nieri, M. (2008) Soft tissue management at implant sites. Journal of Clinical Periodontology 35: 163-167.

Cehreli, M. C., Akca, K. \& Iplikcioglu, H. (2004) Force transmission of one- and twopiece morse-taper oral implants: A nonlinear finite element analysis. Clinical Oral Implants Research 15: 481-489. 
Chen, S. T., Darby, I. B., Reynolds, E. C. \& Clement, J. G. (2009) Immediate implant placement postextraction without flap elevation. Journal of Periodontology 80: 163172.

Cochran, D. L., Nummikoski, P. V., Schoolfield, J. D., Jones, A. A. \& Oates, T. W. (2009) A prospective multicenter 5-year radiographic evaluation of crestal bone levels over time in 596 dental implants placed in 192 patients. Journal of Periodontology 80: 725-733.

Cosyn, J., Hooghe, N. \& De Bruyn, H. (2012a) A systematic review on the frequency of advanced recession following single immediate implant treatment. Journal of Clinical Periodontology 39: 582-589.

Cosyn, J., Sabzevar, M. M. \& De Bruyn, H. (2012b) Predictors of inter-proximal and midfacial recession following single implant treatment in the anterior maxilla: A multivariate analysis. Journal of Clinical Periodontology 39: 895-903.

den Hartog, L., Meijer, H. J., Stegenga, B., Tymstra, N., Vissink, A. \& Raghoebar, G. M. (2011) Single implants with different neck designs in the aesthetic zone: A randomized clinical trial. Clinical Oral Implants Research 22: 1289-1297.

Hermann, J. S., Buser, D., Schenk, R. K., Schoolfield, J. D. \& Cochran, D. L. (2001) Biologic width around one- and two-piece titanium implants. Clinical Oral Implants Research 12: 559-571.

Jung, R., Zembic, A., Pjetursson, B. E., Zwahlen, M. \& D, S. T. (2012a) Systematic review of the survival rate and the incidence of biological, technical, and aesthetic complications of single crowns on implants reported in longitudinal studies with a mean follow-up of 5 years. Clinical Oral Implants Research 23 Suppl 6: 2-21.

Jung, R. E., Benic, G. I., Scherrer, D. \& Hammerle, C. H. (2013) Cone beam computed tomography evaluation of regenerated buccal bone 5 years after simultaneous implant placement and guided bone regeneration procedures - a randomized, controlled clinical trial. Clinical Oral Implants Research.

Jung, R. E., Zembic, A., Pjetursson, B. E., Zwahlen, M. \& Thoma, D. S. (2012b) Systematic review of the survival rate and the incidence of biological, technical, and aesthetic complications of single crowns on implants reported in longitudinal studies with a mean follow-up of 5 years. Clinical Oral Implants Research 23 Suppl 6: 2-21. 
Laurell, L. \& Lundgren, D. (2011) Marginal bone level changes at dental implants after 5 years in function: A meta-analysis. Clinical Implant Dentistry and Related Research 13: 19-28.

Linkevicius, T., Apse, P., Grybauskas, S. \& Puisys, A. (2009a) The influence of soft tissue thickness on crestal bone changes around implants: A 1-year prospective controlled clinical trial. International Journal of Oral and Maxillofacial Implants 24: 712-719.

Linkevicius, T., Apse, P., Grybauskas, S. \& Puisys, A. (2009b) Reaction of crestal bone around implants depending on mucosal tissue thickness. A 1-year prospective clinical study. Stomatologija 11: 83-91.

Papaspyridakos, P., Chen, C. J., Singh, M., Weber, H. P. \& Gallucci, G. O. (2012) Success criteria in implant dentistry: A systematic review. Journal of Dental Research 91: 242-248.

Pjetursson, B. E., Thoma, D., Jung, R., Zwahlen, M. \& Zembic, A. (2012) A systematic review of the survival and complication rates of implant-supported fixed dental prostheses (fdps) after a mean observation period of at least 5 years. Clinical Oral Implants Research 23 Suppl 6: 22-38.

Schneider, D., Grunder, U., Ender, A., Hammerle, C. H. \& Jung, R. E. (2011) Volume gain and stability of peri-implant tissue following bone and soft tissue augmentation: 1-year results from a prospective cohort study. Clinical Oral Implants Research 22: 28-37.

Thoma, D. S., Buranawat, B., Hammerle, C. H., Held, U. \& Jung, R. E. (2014a) Efficacy of soft tissue augmentation around dental implants and in partially edentulous areas: A systematic review. Journal of Clinical Periodontology 41 Suppl 15: S77-91.

Thoma, D. S., Jung, R. E., Schneider, D., Cochran, D. L., Ender, A., Jones, A. A., Gorlach, C., Uebersax, L., Graf-Hausner, U. \& Hammerle, C. H. (2010) Soft tissue volume augmentation by the use of collagen-based matrices: A volumetric analysis. Journal of Clinical Periodontology 37: 659-666.

Thoma, D. S., Sanz Martin, I., Benic, G. I., Roos, M. \& Hammerle, C. H. (2014b) Prospective randomized controlled clinical study comparing two dental implant 
systems: Demographic and radiographic results at one year of loading. Clinical Oral Implants Research 25: 142-149.

Weinlander, M., Lekovic, V., Spadijer-Gostovic, S., Milicic, B., Krennmair, G. \& Plenk, H., Jr. (2009) Gingivomorphometry - esthetic evaluation of the crown-mucogingival complex: A new method for collection and measurement of standardized and reproducible data in oral photography. Clinical Oral Implants Research 20: 526-530.

Windisch, S. I., Jung, R. E., Sailer, I., Studer, S. P., Ender, A. \& Hammerle, C. H. (2007) A new optical method to evaluate three-dimensional volume changes of alveolar contours: A methodological in vitro study. Clinical Oral Implants Research 18: 545551. 
Table 1.

\begin{tabular}{|l|l|l|l|}
\hline $\begin{array}{l}\text { Variables in mm } \\
\text { (Means and SD/Median and IQR) }\end{array}$ & Two-piece group & One-piece group & Significance \\
\hline CH Baseline $(\mathbf{m m})$ & $8.85(1.9) / 8.76(4)$ & $9.7(1.9) / 9.57(3)$ & 0.244 \\
\hline eTT1 Baseline & $0.75(0.31) / 0.66(0)$ & $0.93(0.52) / 0.76(0)$ & 0.290 \\
\hline eTT3 Baseline & $1.31(0.78) / 1.23(1)$ & $1.46(0.93) / 1.12(1)$ & 0.735 \\
\hline eTT5 Baseline & $1.82(1.08) / 1.77(1.2)$ & $1.70(1.13) / 1.66(0.9)$ & 0.451 \\
\hline DIB Baseline $\mathbf{( m m )}$ & $0.93(0.42) / 1.01(0.56)$ & $0.68(0.93) / 0.42(0.71)$ & 0.11 \\
\hline
\end{tabular}

Table 2.

\begin{tabular}{|l|l|l|l|}
\hline $\begin{array}{l}\text { Variables in mm } \\
\text { (Means and SD } \\
\text { /Median and IQR) }\end{array}$ & Two-piece group & One-piece group & Significance \\
\hline $\begin{array}{l}\text { Crown Height Changes } \\
\text { in mm (CHC) }\end{array}$ & $0.02(0.32) / 0.04(0.43)$ & $-0.17(0.58) /-0.04(1.17)$ & 0.405 \\
\hline $\begin{array}{l}\text { Volume Changes } \\
\text { (VC) in mm }\end{array}$ & $-0.12(0.27) /-0.12(0.33)$ & $-0.03(0.29) / 0.02(0.45)$ & 0.233 \\
\hline $\begin{array}{l}\text { Change at the 1 mm } \\
\text { measurement point }\end{array}$ & $-0.15(0.20) /-0.2(0.23)$ & $-0.03(0.35) / 0.07(0.52)$ & 0.104 \\
\hline $\begin{array}{l}\text { Change at the 3mm } \\
\text { measurement point }\end{array}$ & $-0.06(0.20) /-0.06(0.25)$ & $0.01(0.28) / 0.01(0.43)$ & 0.385 \\
\hline $\begin{array}{l}\text { Change at the 5mm } \\
\text { measurement point }\end{array}$ & $-0.2(0.51) /-0.1(0.72)$ & $-0.01(0.51) /-0.1(0.68)$ & 0.449 \\
\hline \begin{tabular}{l} 
Changes in DIB (mm) \\
\hline
\end{tabular} & $0.08(0.2) / 0.09(0.23)$ & $0.35(0.35) / 0.35(0.36)$ & $0.01 *$ \\
\hline
\end{tabular}


Table 3.

\begin{tabular}{|c|c|c|c|c|c|c|}
\hline & $\begin{array}{l}\text { Change at } \\
\text { the } 1 \mathrm{~mm} \\
\text { measureme } \\
\text { nt point }\end{array}$ & $\begin{array}{l}\text { Change at } \\
\text { the } 3 \mathrm{~mm} \\
\text { measureme } \\
\text { nt point }\end{array}$ & $\begin{array}{l}\text { Change at } \\
\text { the } 5 \mathrm{~mm} \\
\text { measureme } \\
\text { nt point }\end{array}$ & VC & CHC & DIB \\
\hline $\begin{array}{l}\text { Change at } \\
\text { the } 1 \mathrm{~mm} \\
\text { measureme } \\
\text { nt point }\end{array}$ & --- & $0.53(0.02 *)$ & $0.33(0.21)$ & $\begin{array}{l}0.55(0.01 \\
*)\end{array}$ & $\begin{array}{l}- \\
0.38(0.1 \\
1)\end{array}$ & $\begin{array}{l}0.27(0.2 \\
7)\end{array}$ \\
\hline $\begin{array}{l}\text { Change at } \\
\text { the } 3 \mathrm{~mm} \\
\text { measureme } \\
\text { nt point }\end{array}$ & $0.53(0.02 *)$ & --- & $0.58(0.02 *)$ & $0.38(0.12)$ & $\begin{array}{l}- \\
0.33(0.1 \\
7)\end{array}$ & $\begin{array}{l}0.21(0.3 \\
9)\end{array}$ \\
\hline $\begin{array}{l}\text { Change at } \\
\text { the } 5 \mathrm{~mm} \\
\text { measureme } \\
\text { nt point }\end{array}$ & $0.33(0.21)$ & $0.58\left(0.02^{*}\right)$ & --- & $0.21(0.47)$ & $\begin{array}{l}- \\
0.2(0.46)\end{array}$ & $\begin{array}{l}0.03(0.8 \\
9)\end{array}$ \\
\hline VC & $0.55(0.01 *)$ & $0.38(0.12)$ & $0.21(0.47)$ & --- & $-0.6(0.8)$ & $\begin{array}{l}0.36(0.8 \\
9)\end{array}$ \\
\hline CHC & $-0.38(0.11)$ & $-0.33(0.17)$ & $-0.2(0.46)$ & $-0.6(0.8)$ & --- & $\begin{array}{l}- \\
0.11(0.6 \\
4)\end{array}$ \\
\hline DIB & $0.27(0.27)$ & $0.21(0.39)$ & $0.03(0.89)$ & $0.36(0.89)$ & $\begin{array}{l}- \\
0.11(0.6 \\
4)\end{array}$ & --- \\
\hline
\end{tabular}


Table 4.

\begin{tabular}{|c|c|c|c|c|c|c|}
\hline & $\begin{array}{l}\text { Change at } \\
\text { the } 1 \mathrm{~mm} \\
\text { measurem } \\
\text { ent point }\end{array}$ & $\begin{array}{l}\text { Change at } \\
\text { the } 3 \mathrm{~mm} \\
\text { measure } \\
\text { ment } \\
\text { point }\end{array}$ & $\begin{array}{l}\text { Change } \\
\text { at the } \\
5 \mathrm{~mm} \\
\text { measure } \\
\text { ment } \\
\text { point }\end{array}$ & VC & CHC & DIB \\
\hline $\begin{array}{l}\text { Change at the } \\
1 \mathrm{~mm} \\
\text { measurement } \\
\text { point }\end{array}$ & --- & $0.66(0.04 *)$ & $0.65(0.01 *)$ & $0.7(<0.01 *)$ & $0.3(0.13)$ & $-0.22(0.21)$ \\
\hline $\begin{array}{l}\text { Change at the } \\
3 \mathrm{~mm} \\
\text { measurement } \\
\text { point }\end{array}$ & $0.66(0.04 *)$ & --- & $0.8(<0.01 *)$ & $0.6(0.004 *)$ & $0.05(0.43)$ & $0.000(0.5)$ \\
\hline $\begin{array}{l}\text { Change at the } \\
5 \mathrm{~mm} \\
\text { measurement } \\
\text { point }\end{array}$ & $0.65\left(0.01^{*}\right)$ & $0.8\left(<0.01^{*}\right)$ & --- & $0.72(0.04 *)$ & $-0.28(0.18)$ & $0.21(0.25)$ \\
\hline VC & $0.7(<0.01 *)$ & $0.6(0.004 *)$ & $0.72(0.04 *)$ & --- & $0.35(0.09)$ & $-0.18(0.25)$ \\
\hline CHC & $0.3(0.13)$ & $0.05(0.43)$ & $-0.28(0.18)$ & $0.35(0.09)$ & --- & $-0.04(0.43)$ \\
\hline DIB & $-0.22(0.21)$ & $0.000(0.5)$ & $0.21(0.25)$ & $-0.18(0.25)$ & $-0.04(0.43)$ & --- \\
\hline
\end{tabular}


Figure 1.

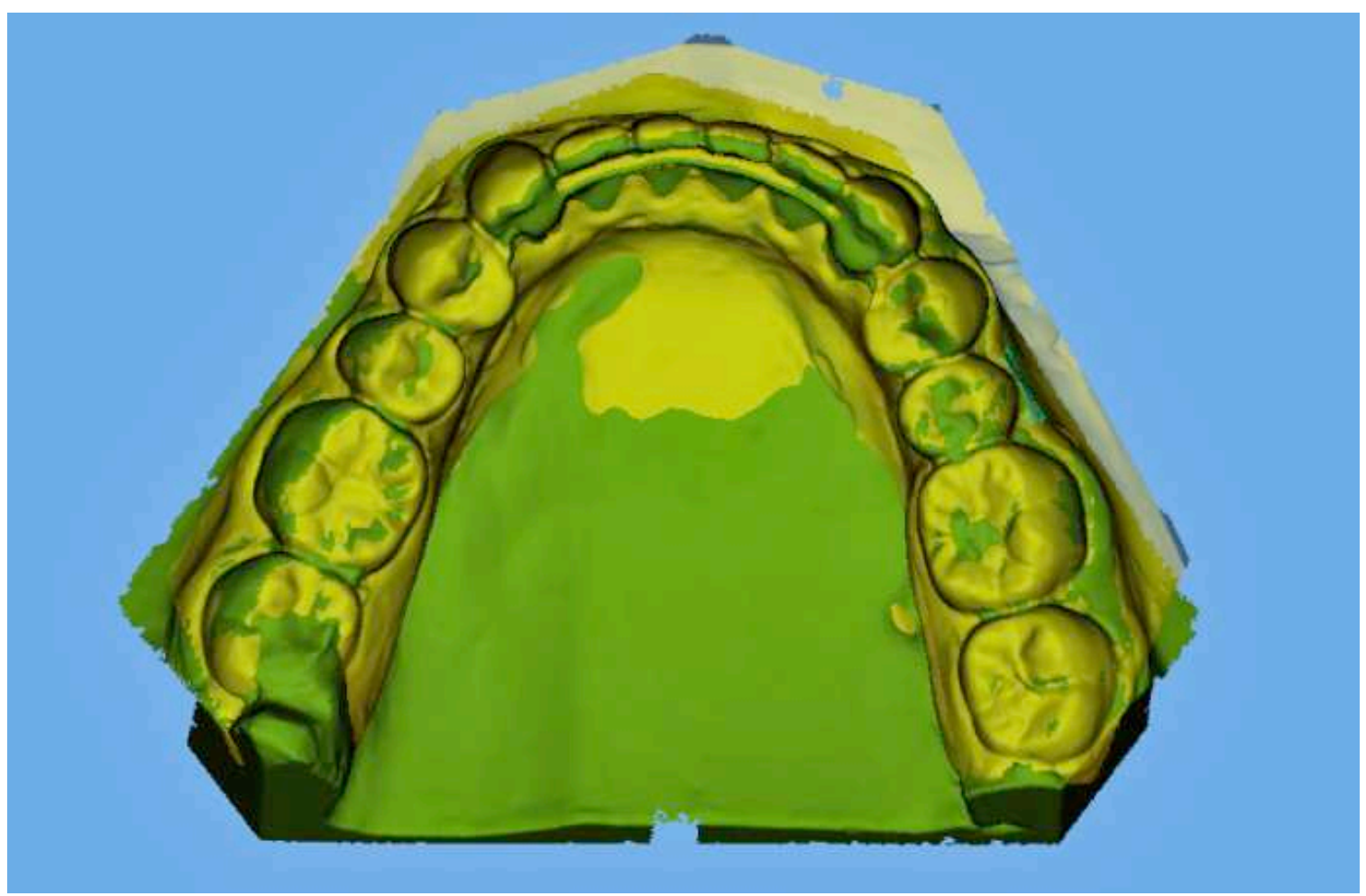


Figure 2

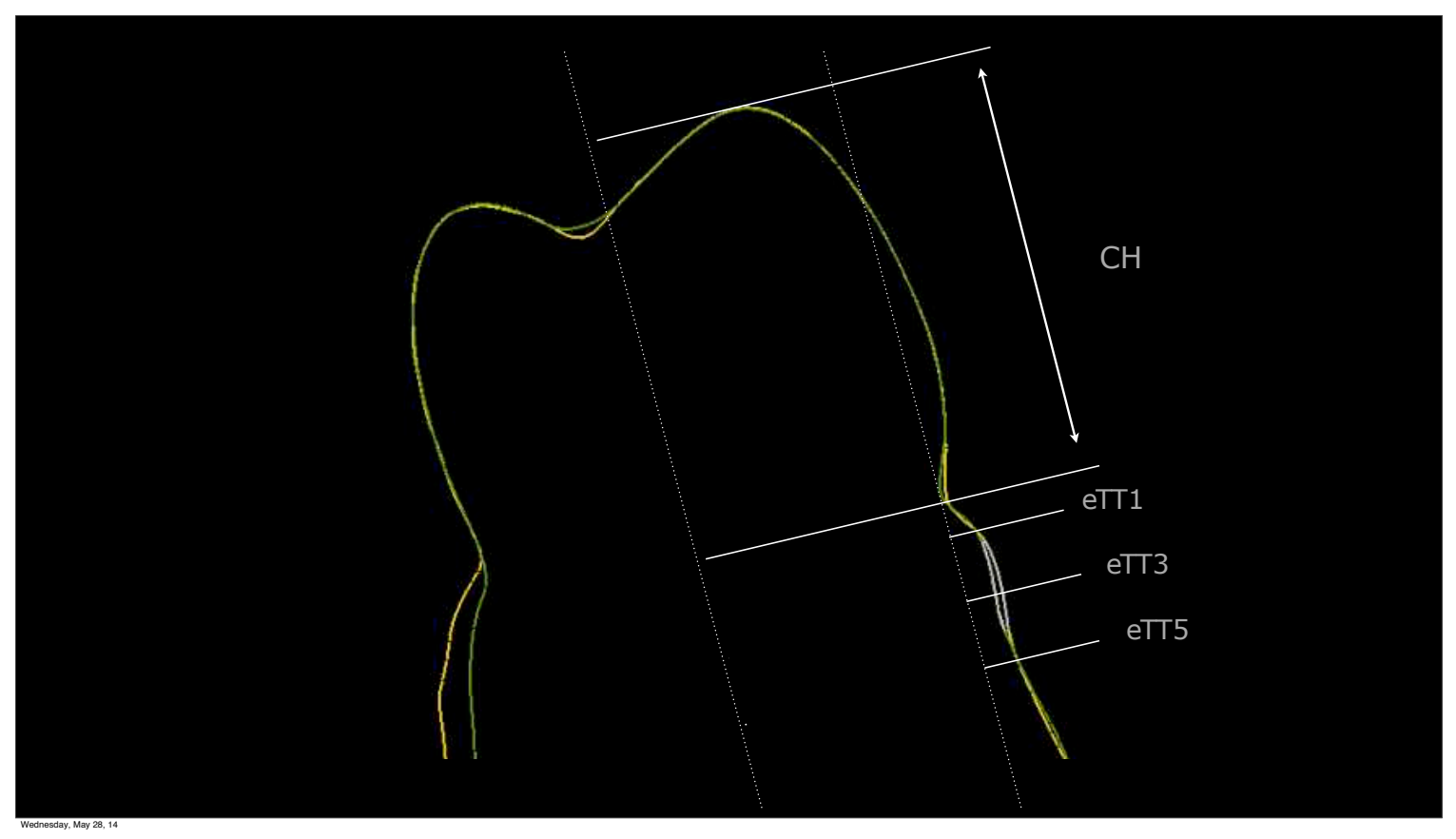


Figure 3

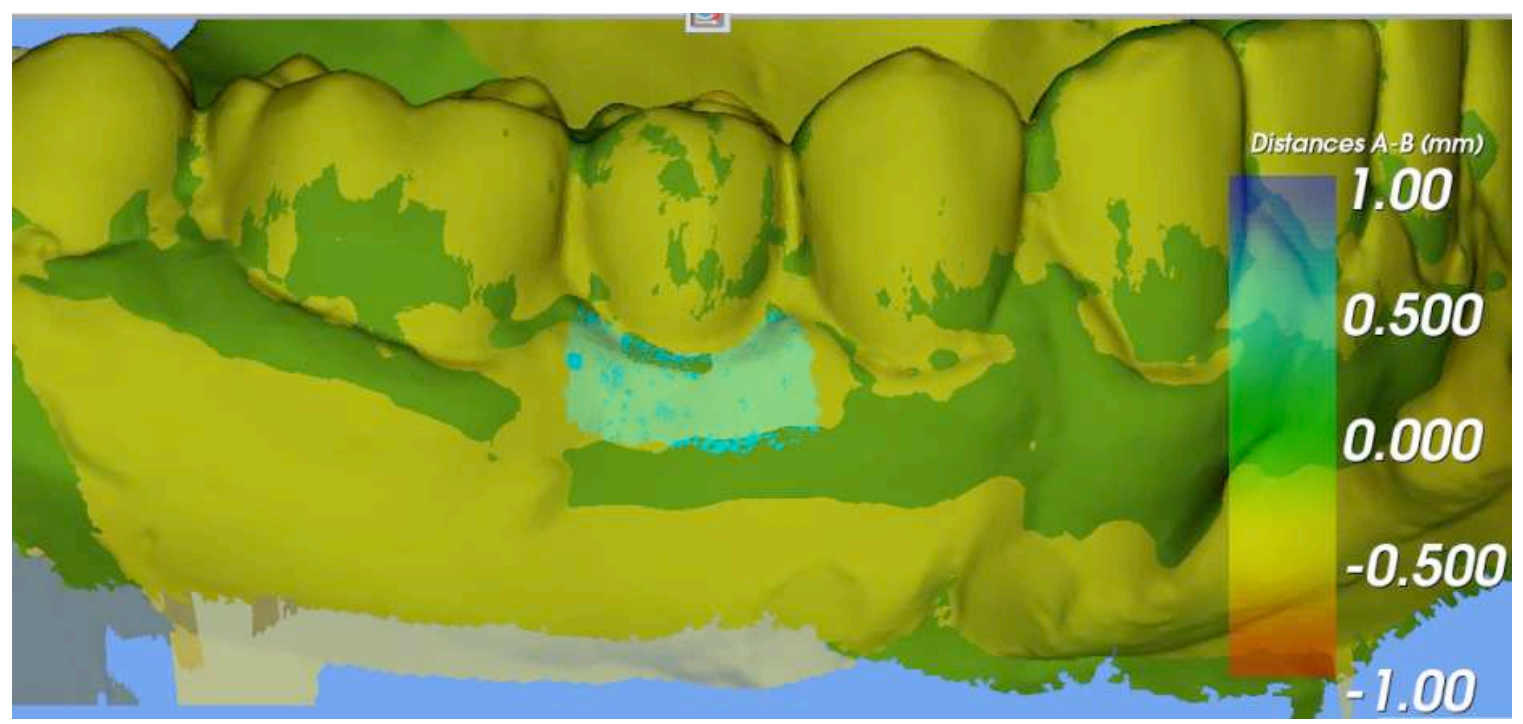


